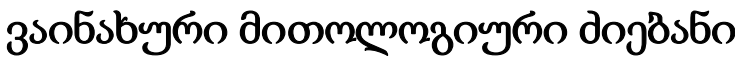

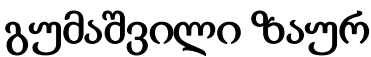

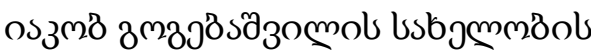

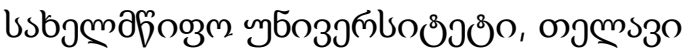

https://doi.org/10.52340/idw.2021.499

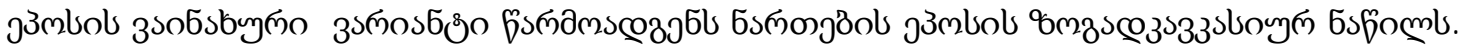

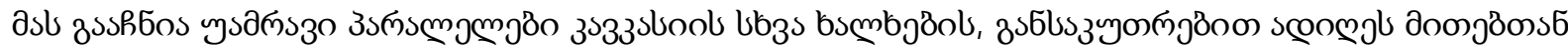

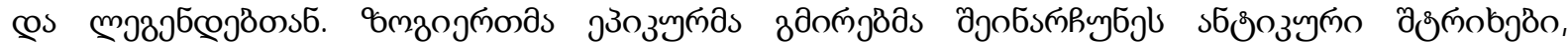

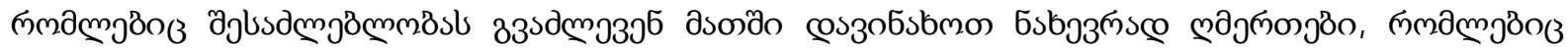

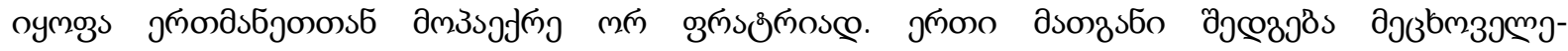

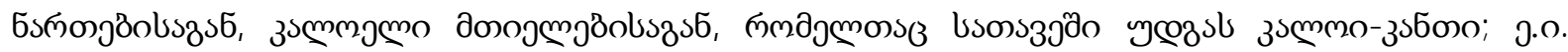

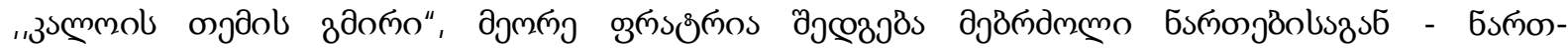

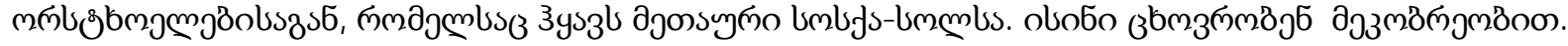

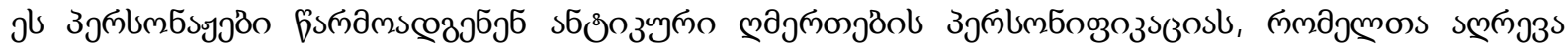

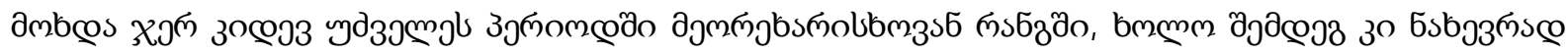

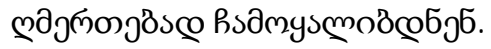

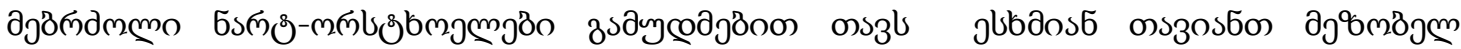

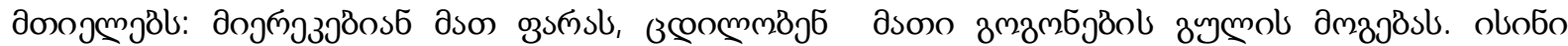

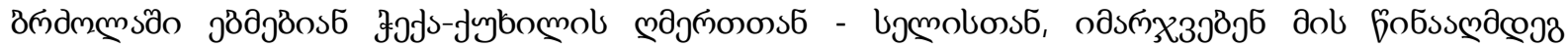

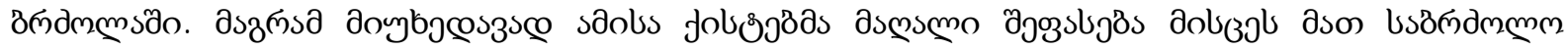

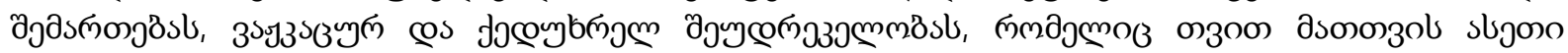

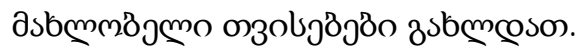

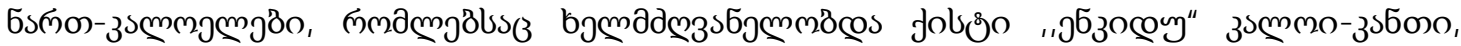

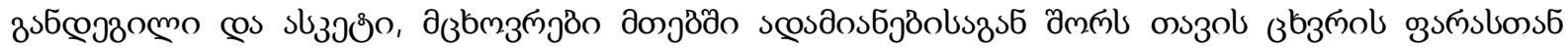

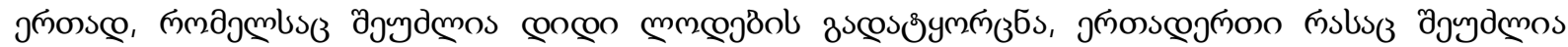

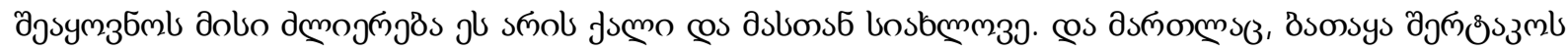

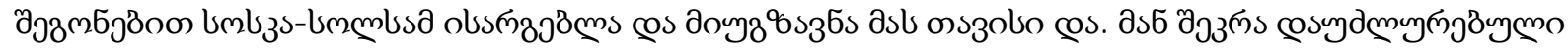

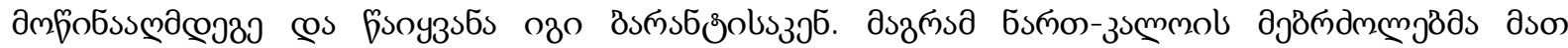

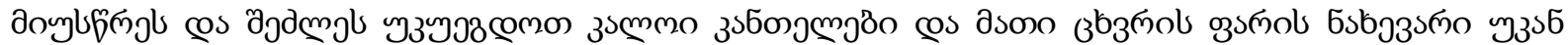

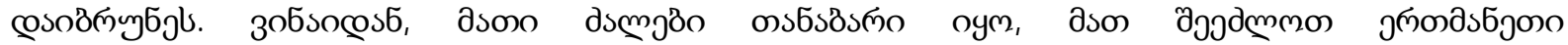

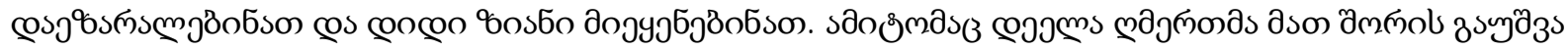

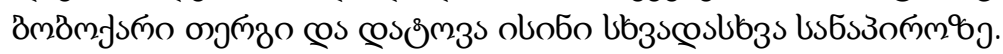

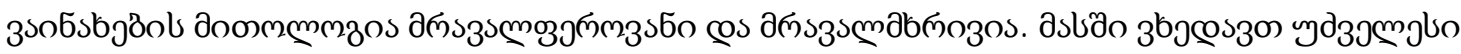

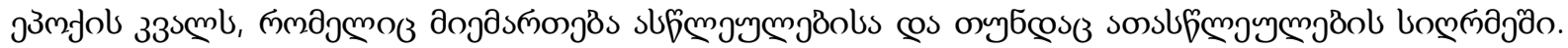

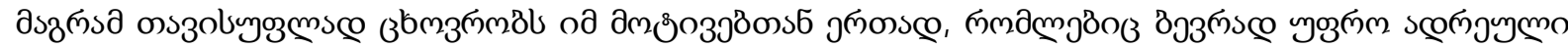

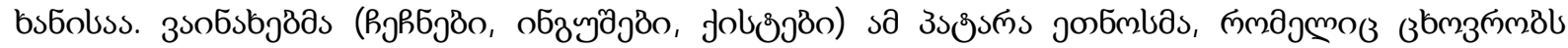

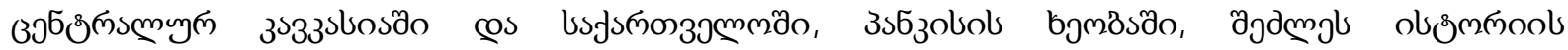

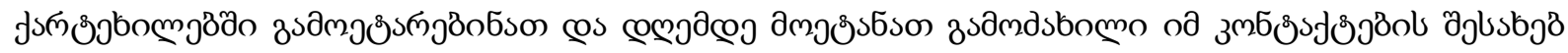

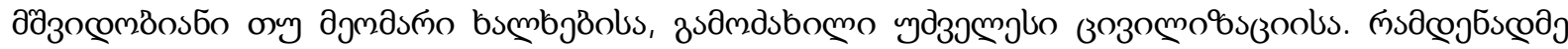

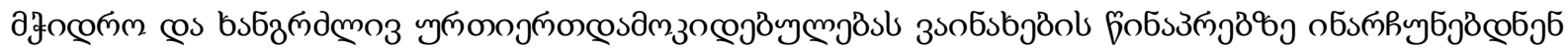

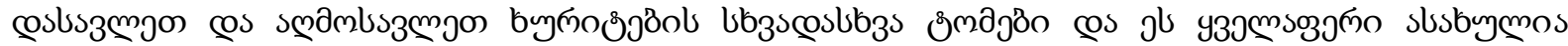




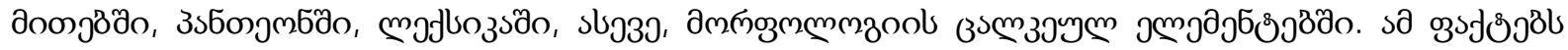

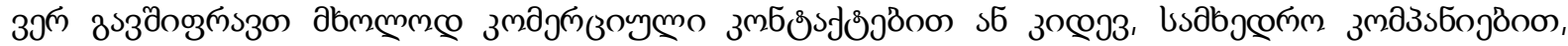

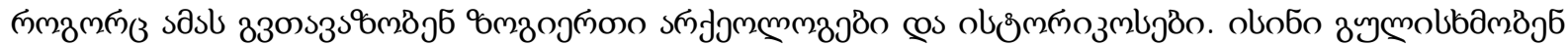

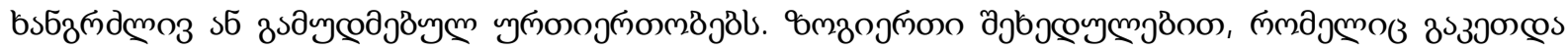

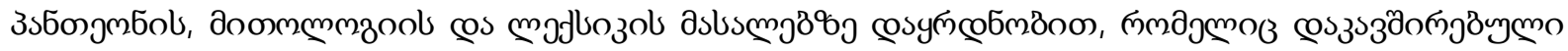

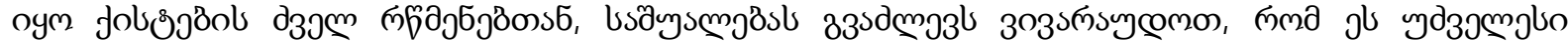

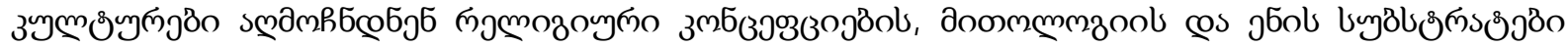
asono d 32 mo fo6s3m

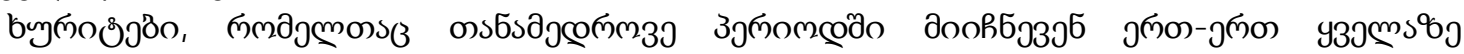

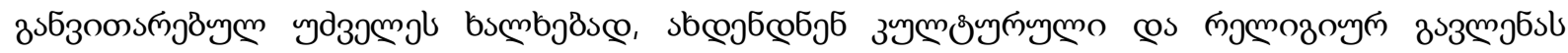

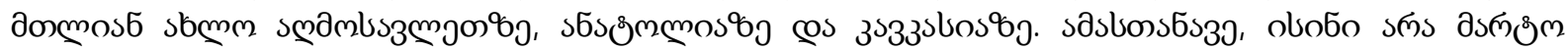

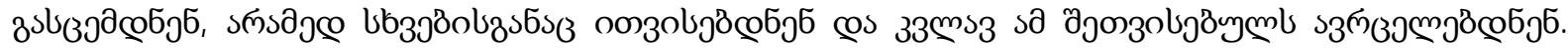

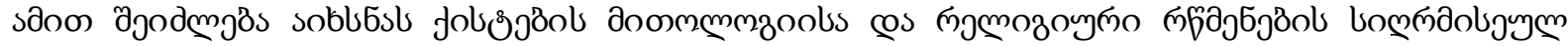

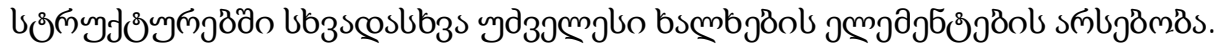

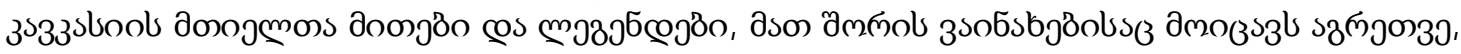

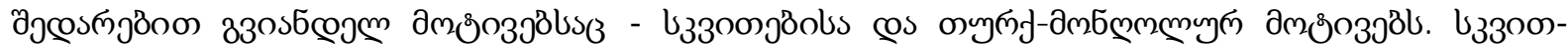

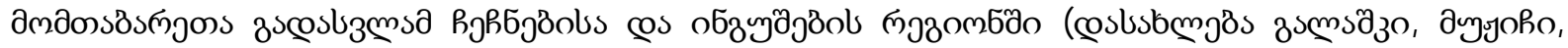

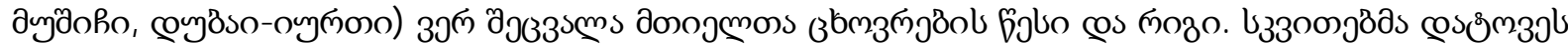

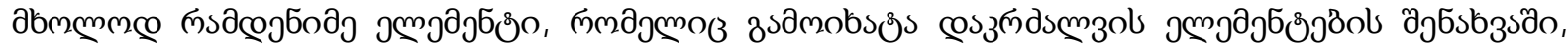

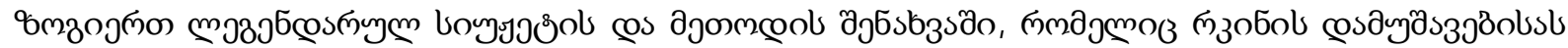

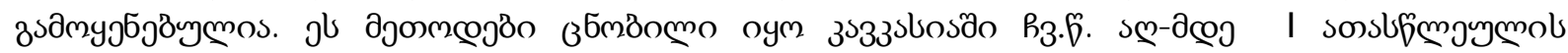

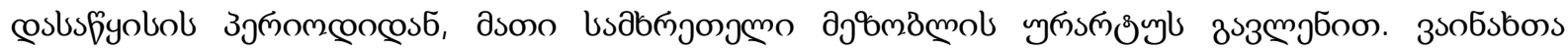

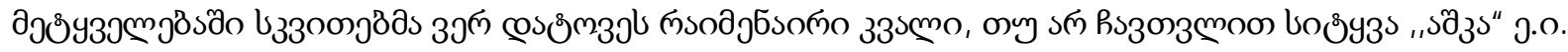

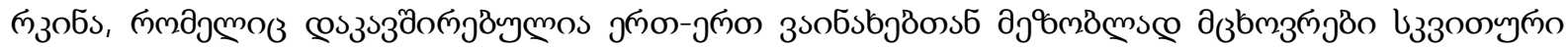

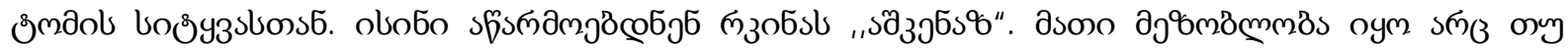

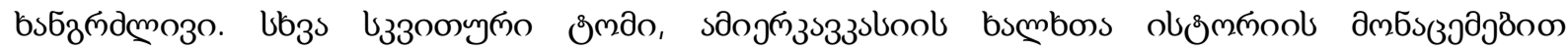

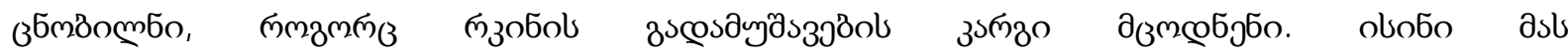

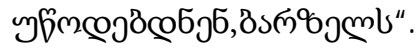

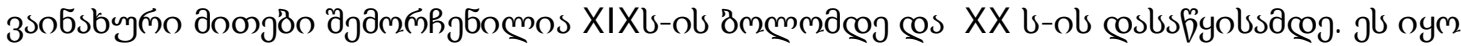

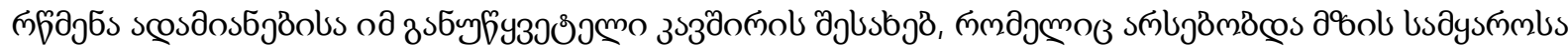

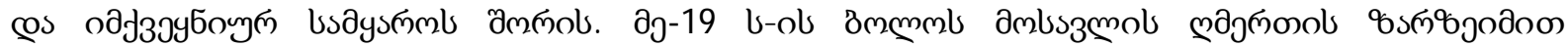

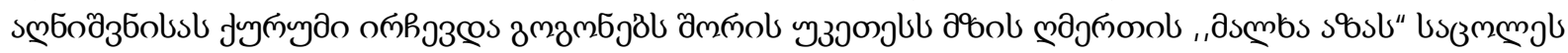

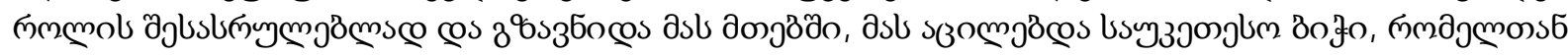

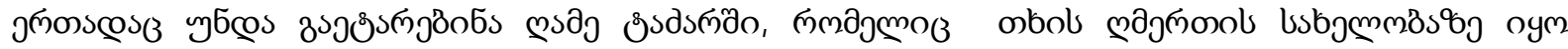
sдjб

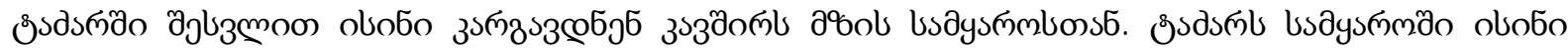

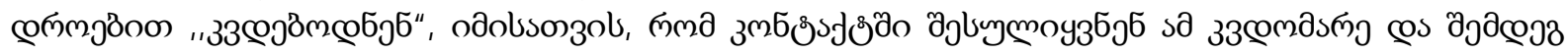

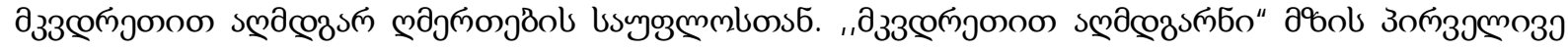

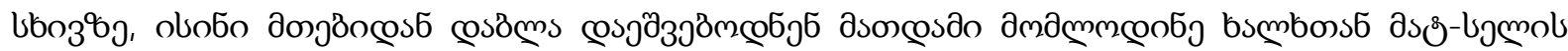

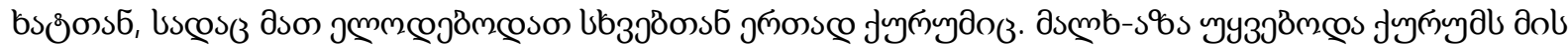

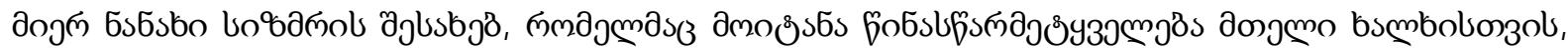

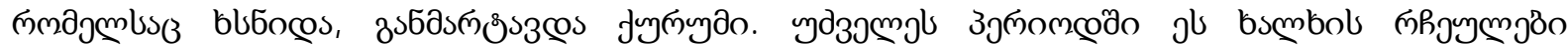

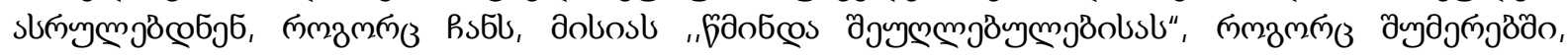

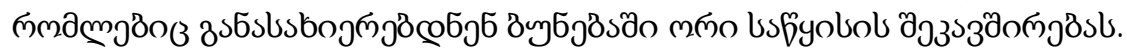

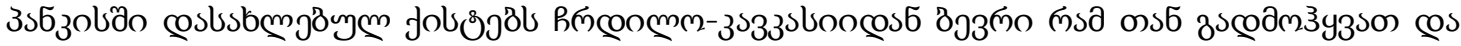

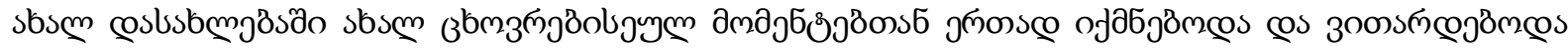

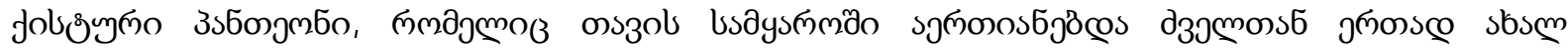

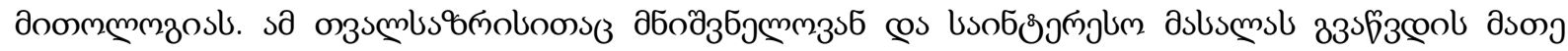

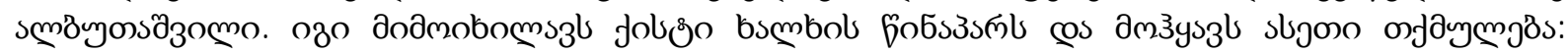

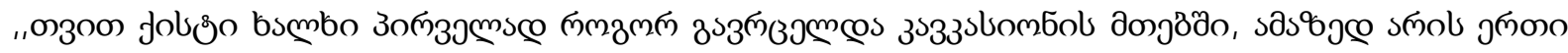




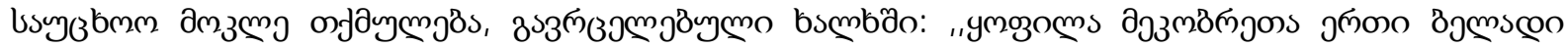

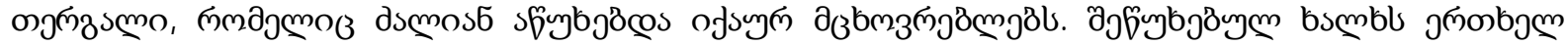

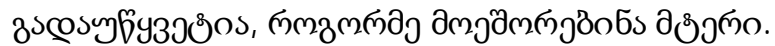

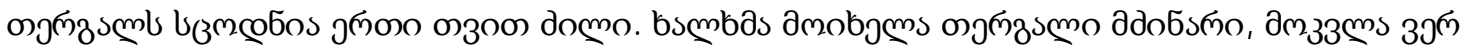

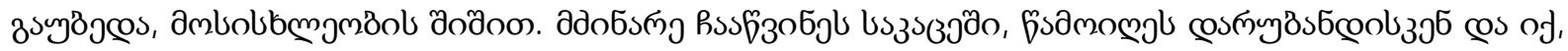

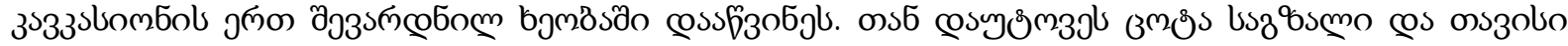

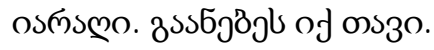

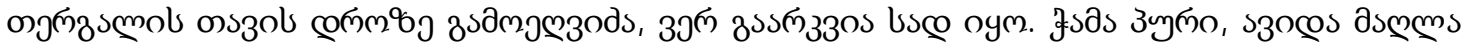

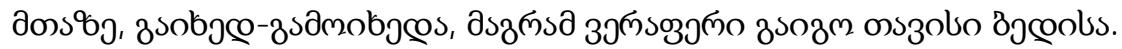

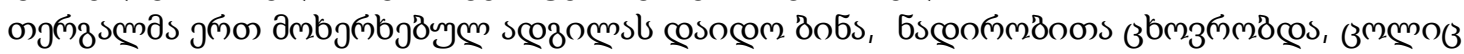

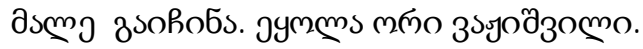

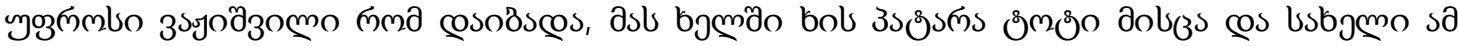

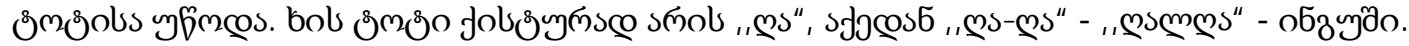

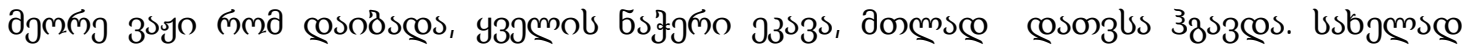

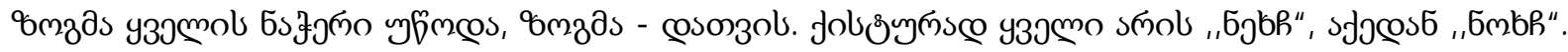

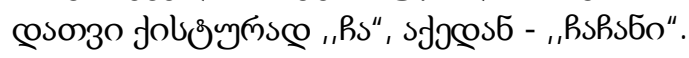

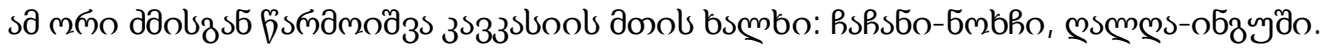

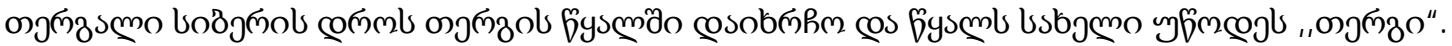

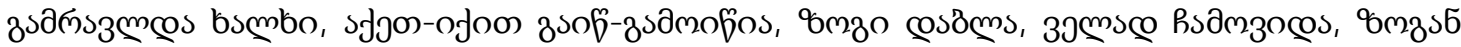

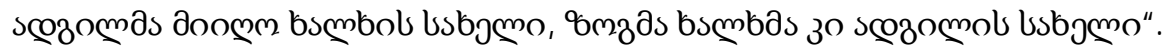

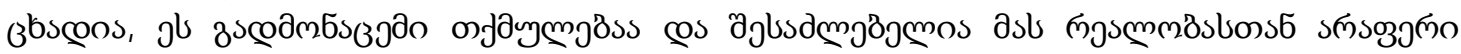

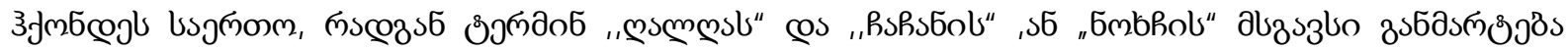

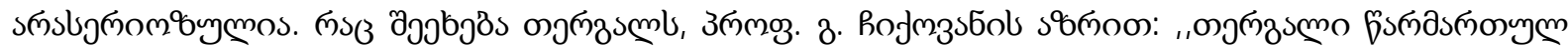

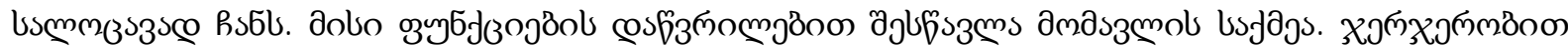

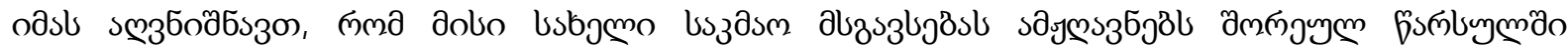

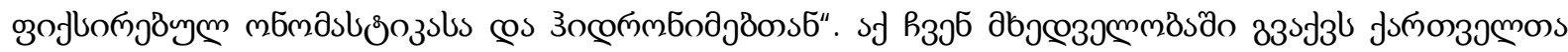

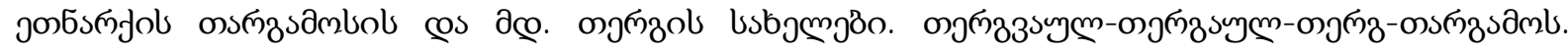

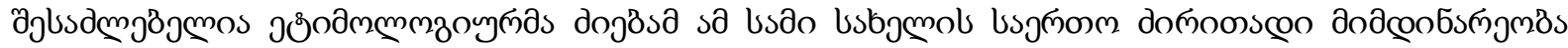
cosscosbofynmb". [5:301]

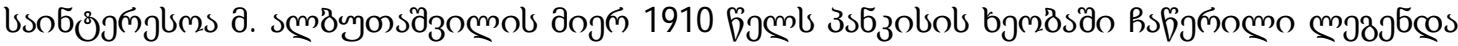

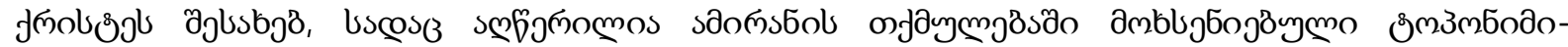

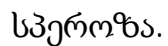

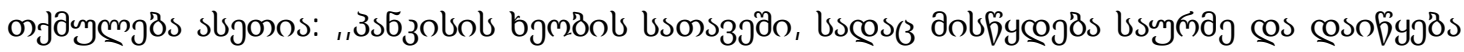

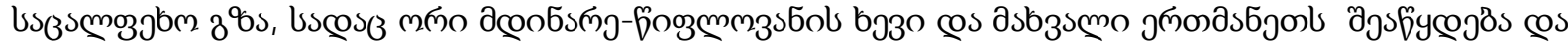

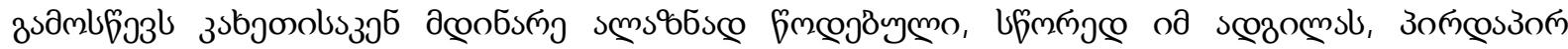

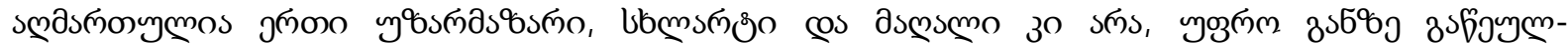

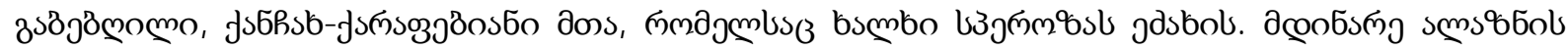

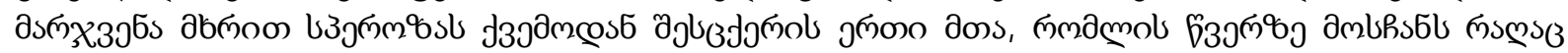

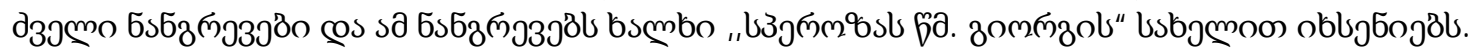

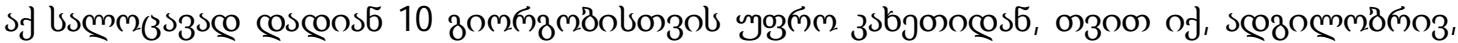

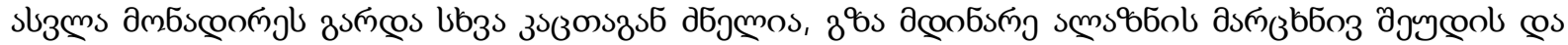

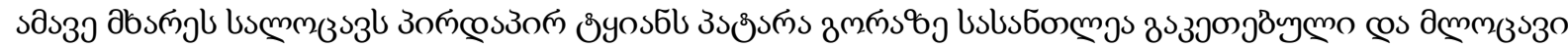

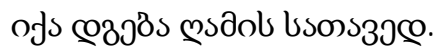

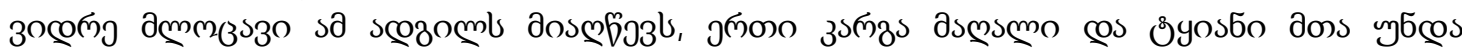
зscososmml.

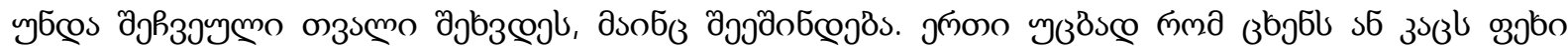

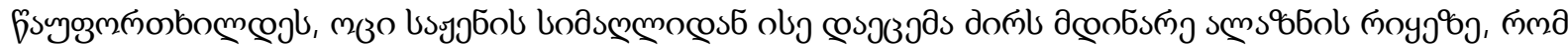

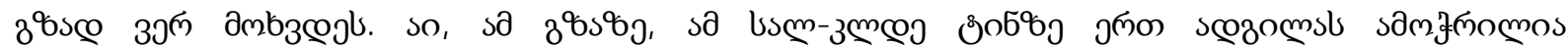

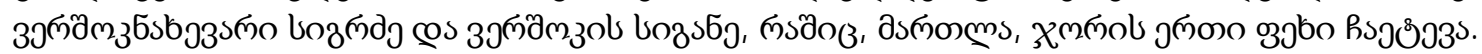

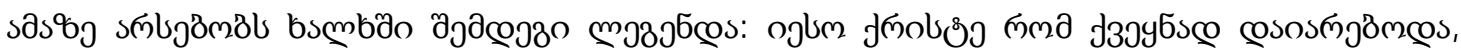




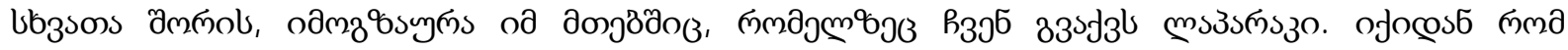

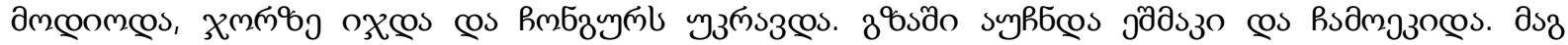

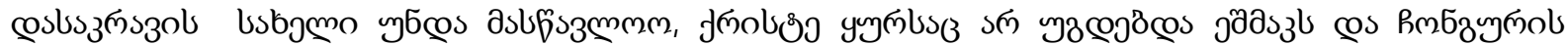

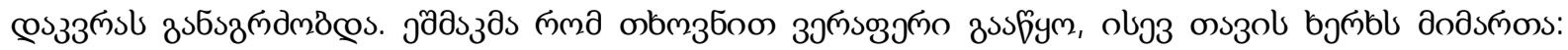
j๓оbơ

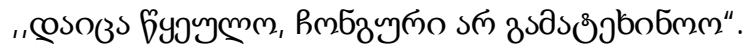

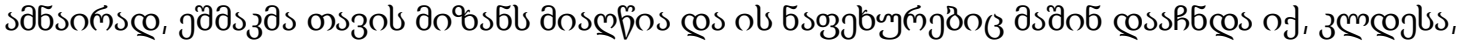

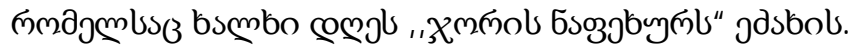

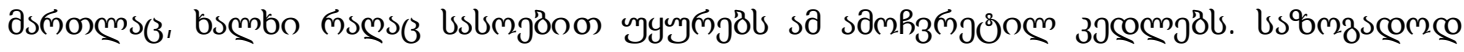

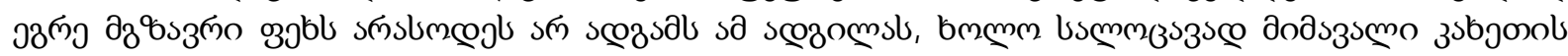

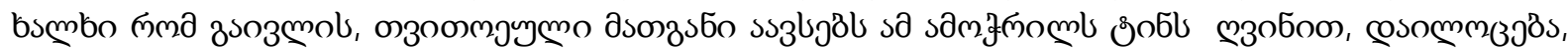

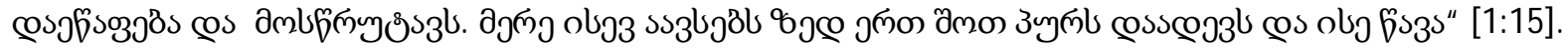

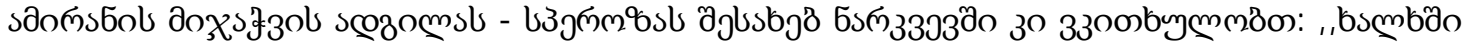

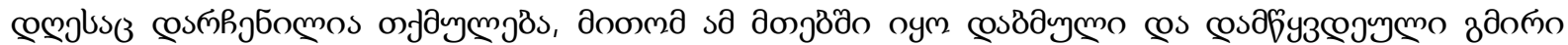

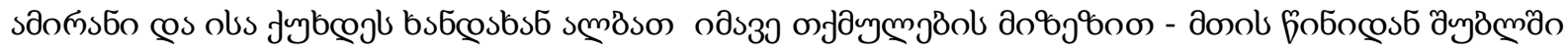

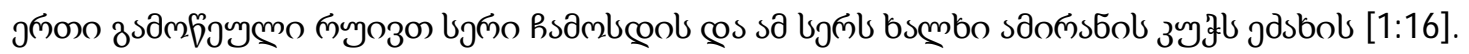

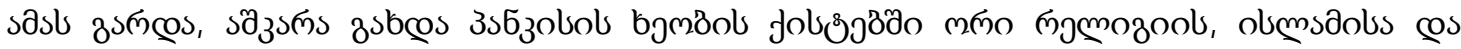

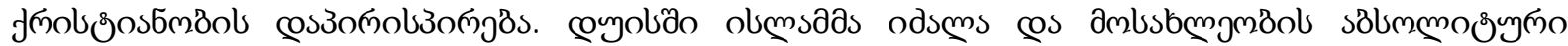

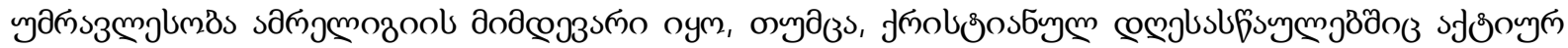

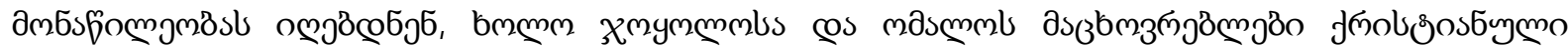

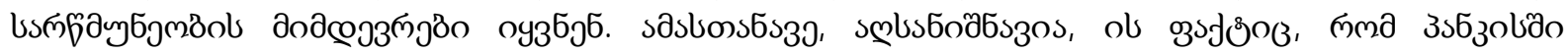

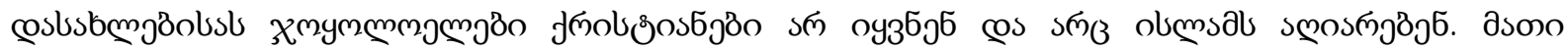

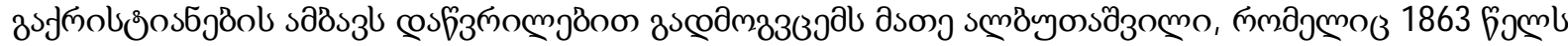

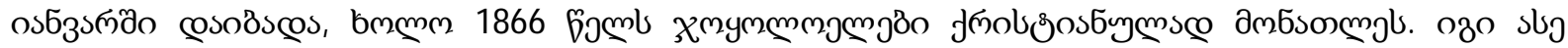

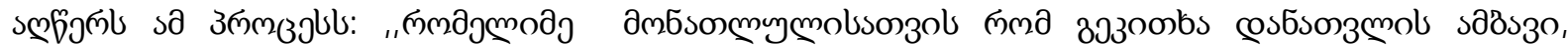

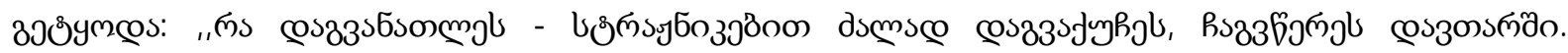

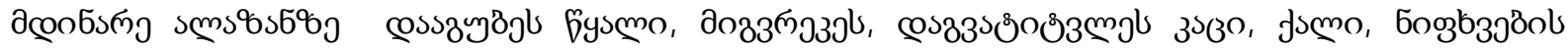

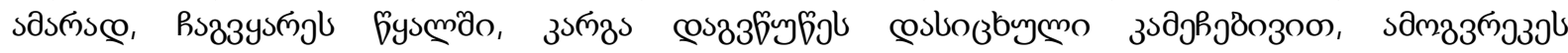

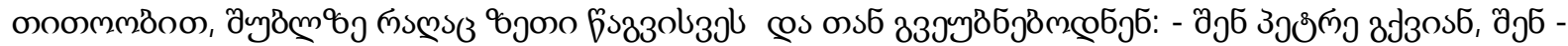

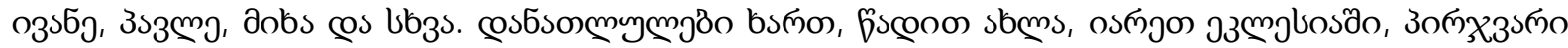

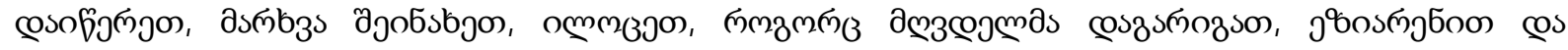

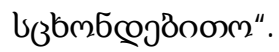

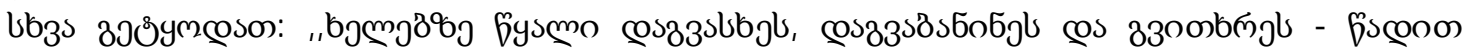

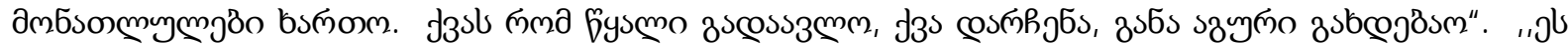

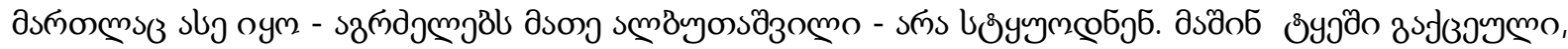

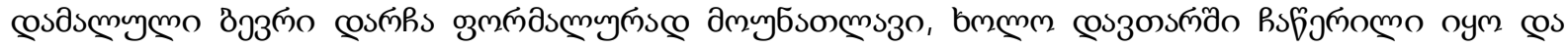

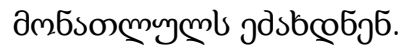

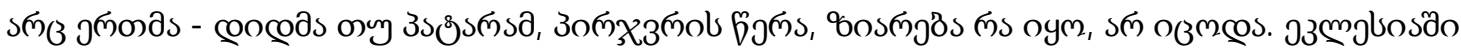

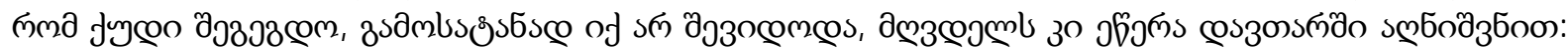

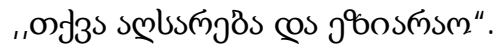

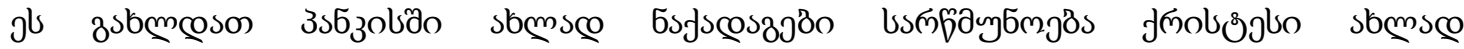

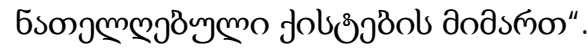

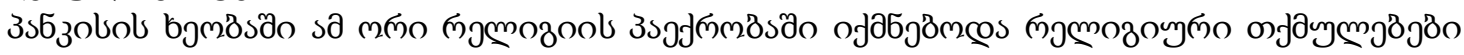

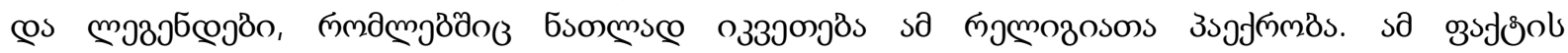

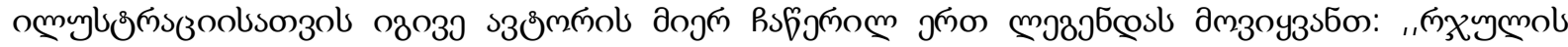

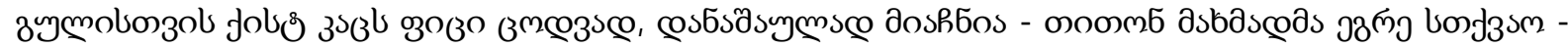

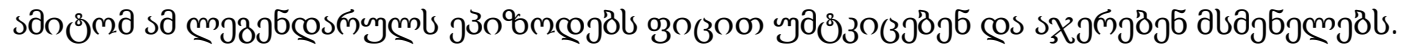

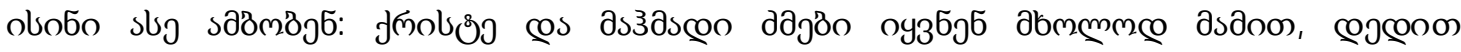

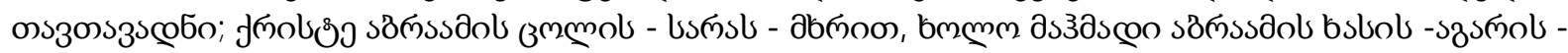

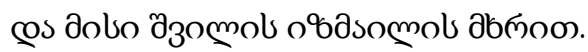




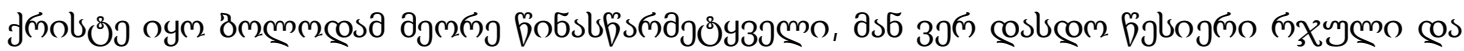

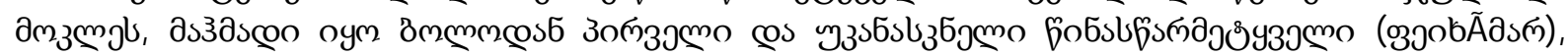

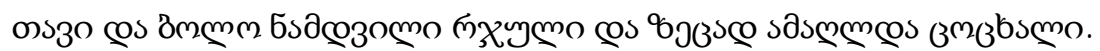

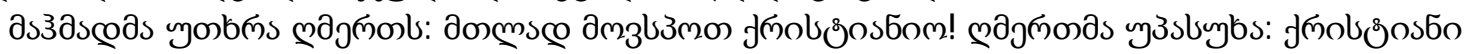

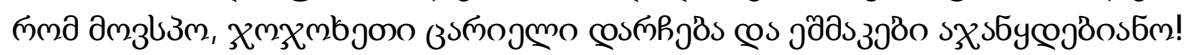

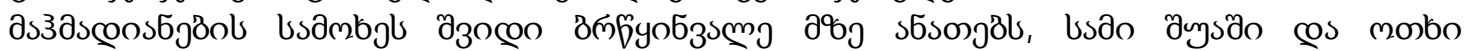

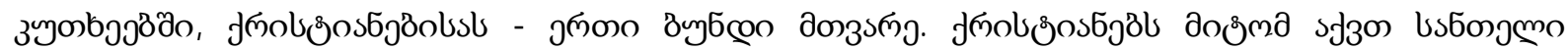
дмzмбомо .

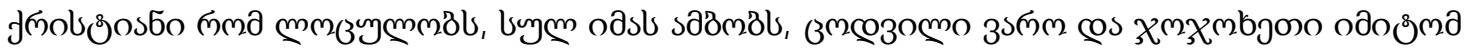
smol bszymon

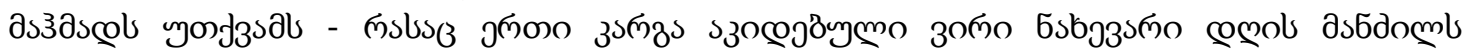

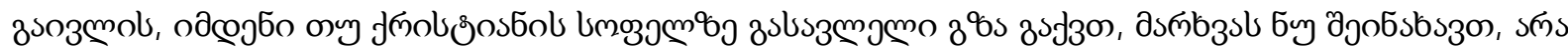
ỹas 3 b.

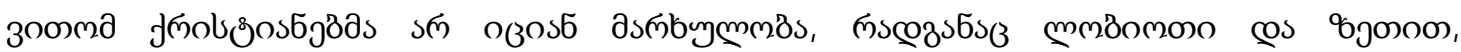

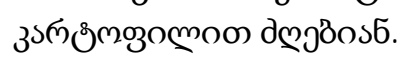

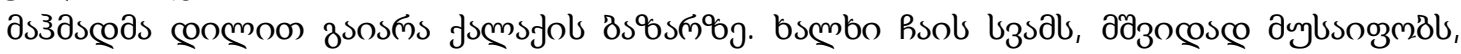

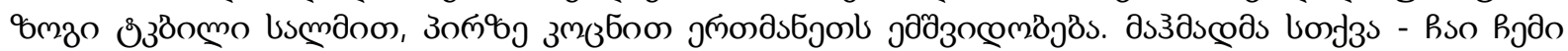

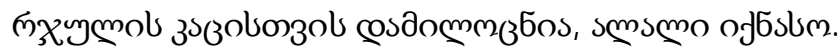

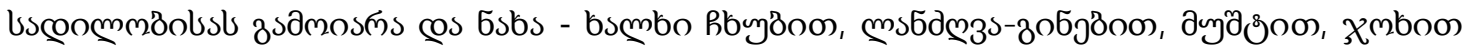

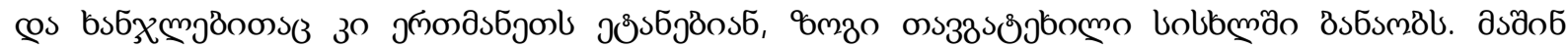

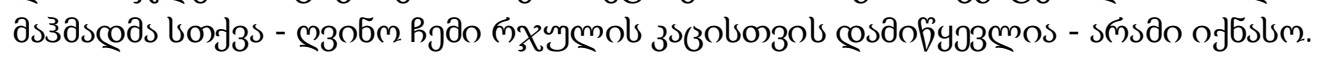

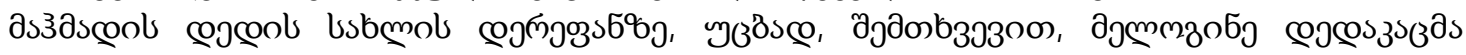

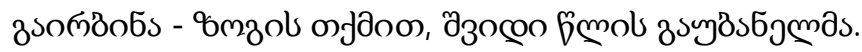

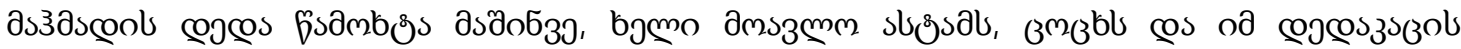

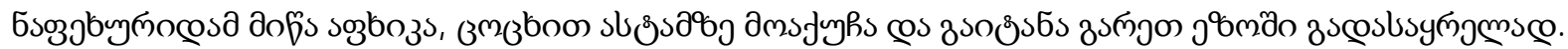

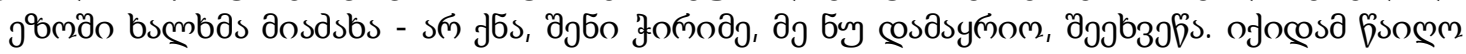
бysmäo zscostsymjmsco.

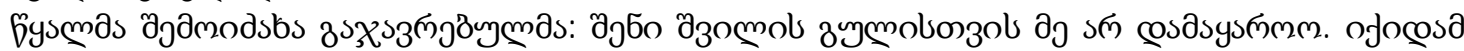

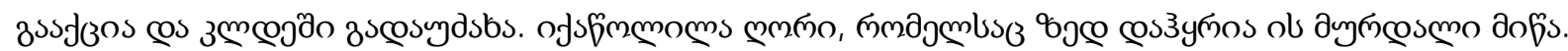

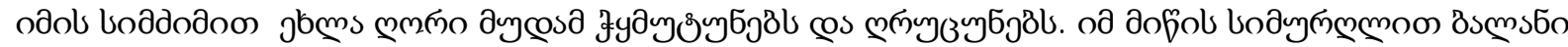

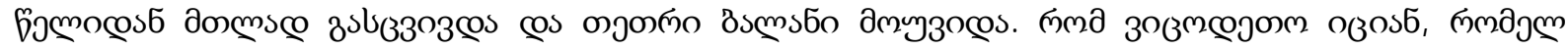

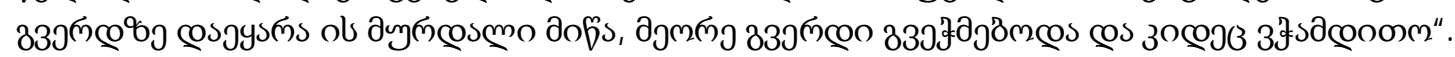

дsм'

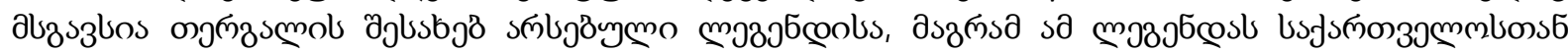

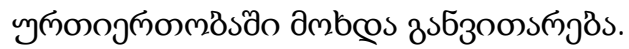

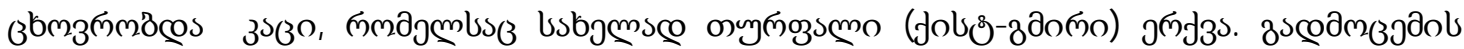

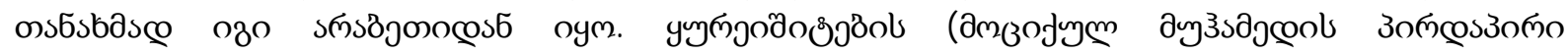

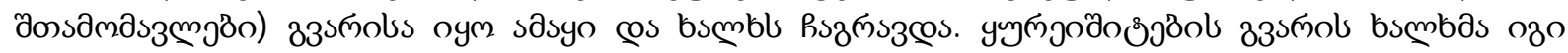

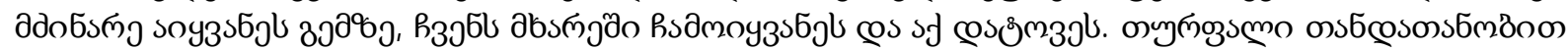

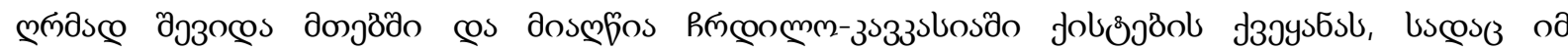

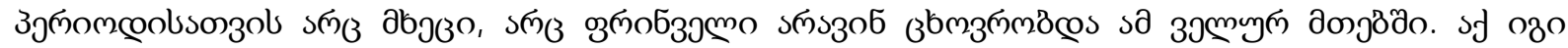

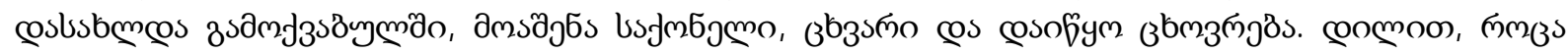

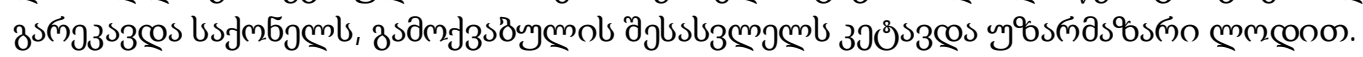

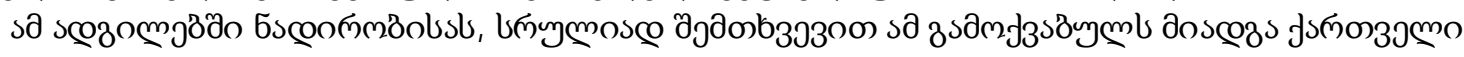

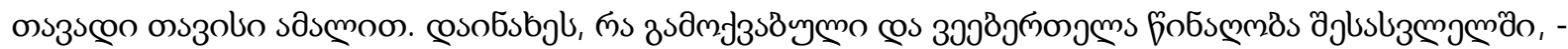

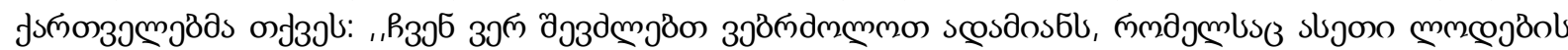

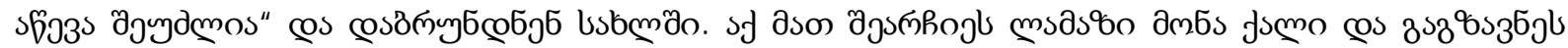

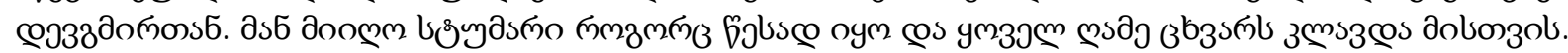

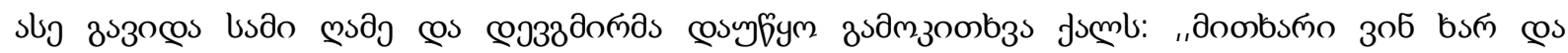

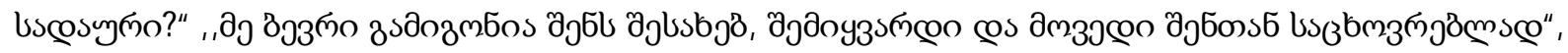




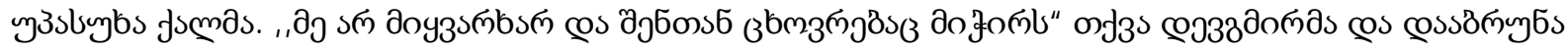

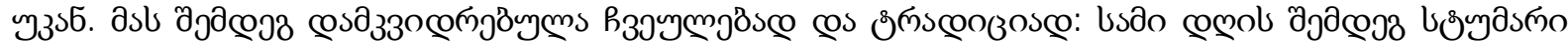

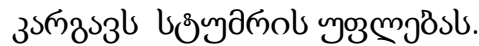

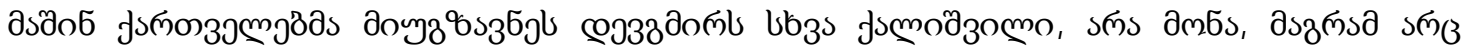

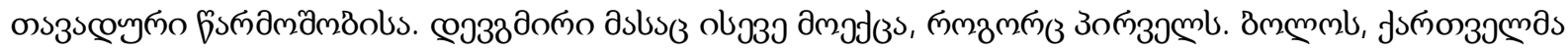

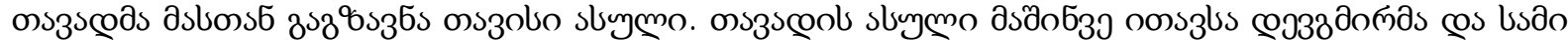

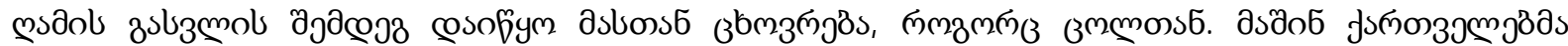

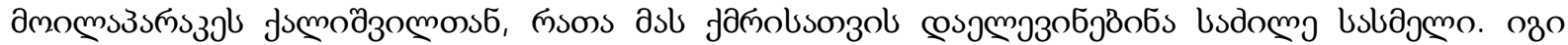

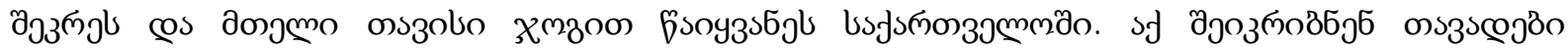

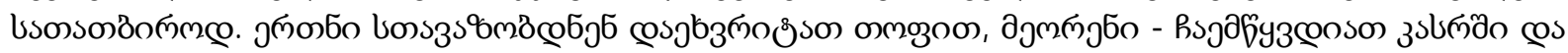

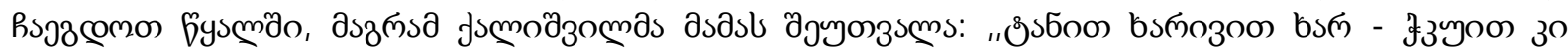

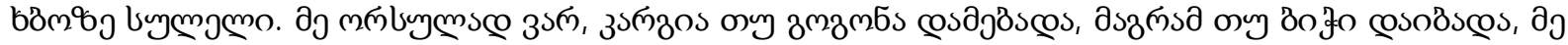

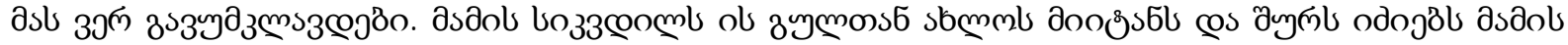
bobbenolssonzol".

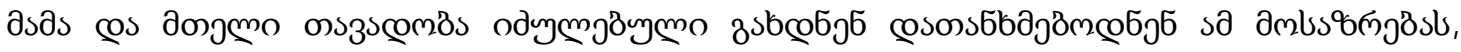

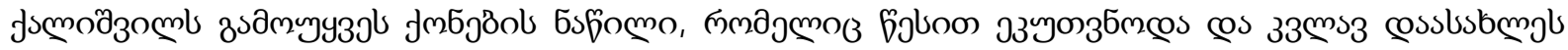
œ

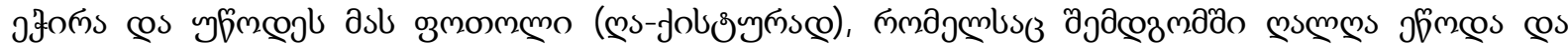

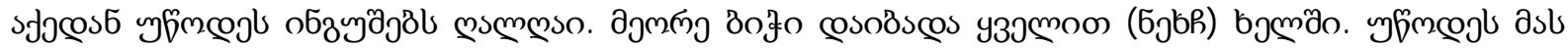

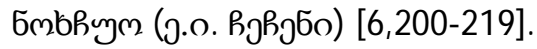

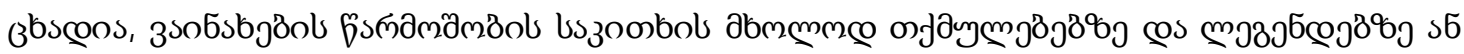

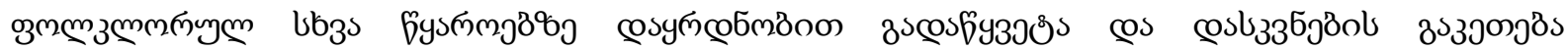

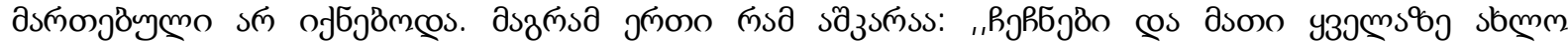

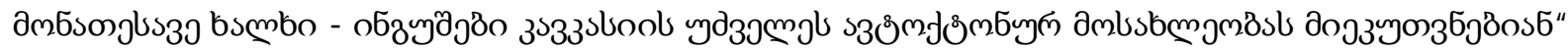
$[7,12]$.

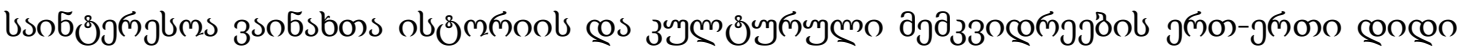

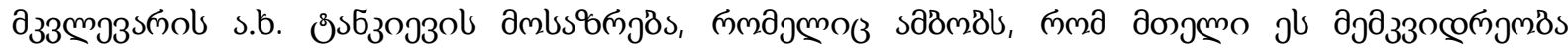

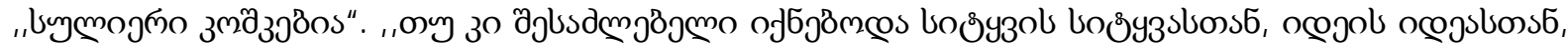

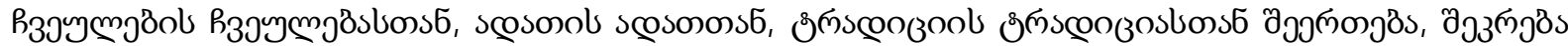

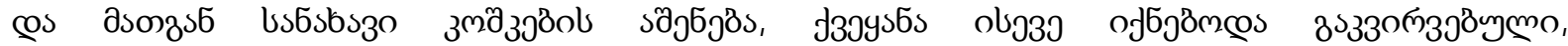

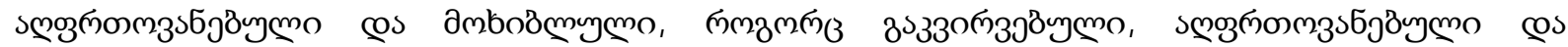

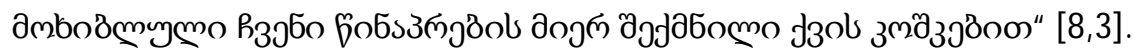

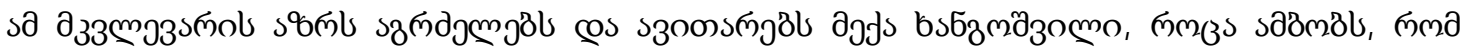

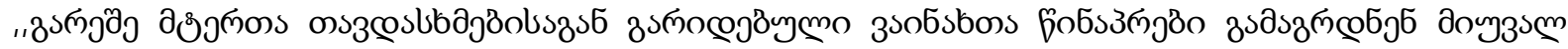

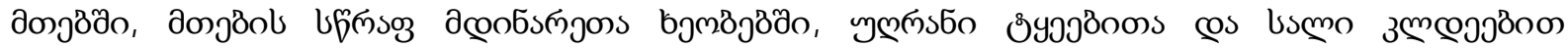

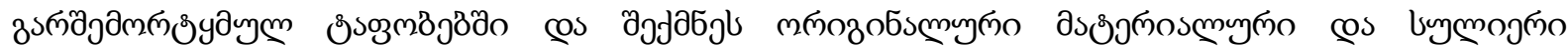

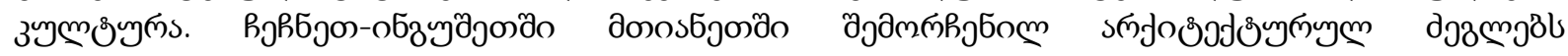

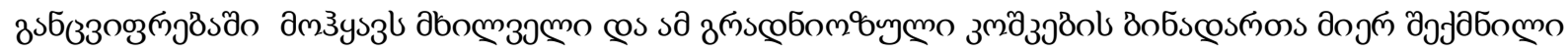

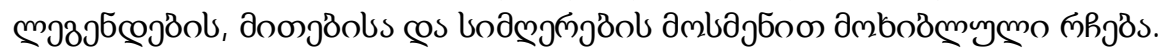

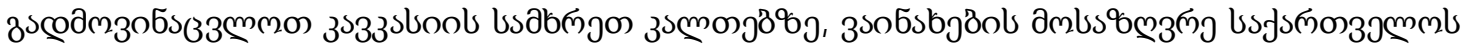

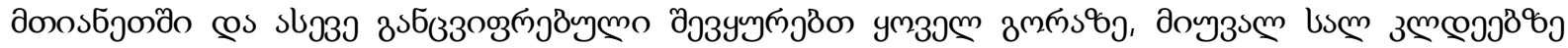

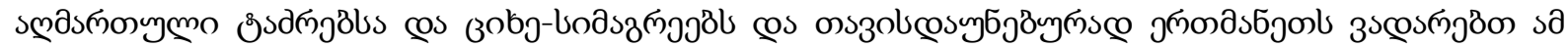

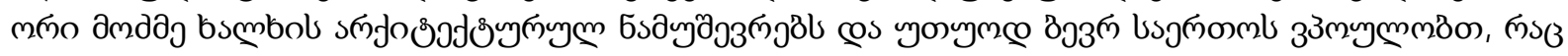

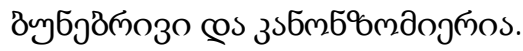

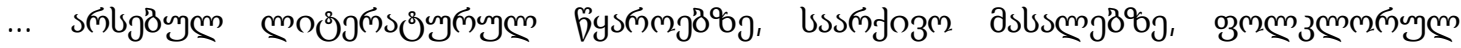

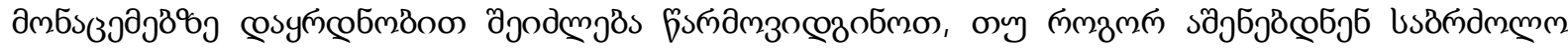

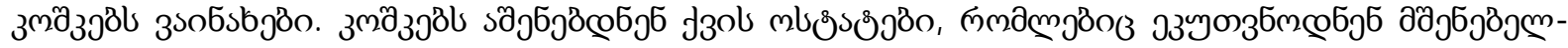

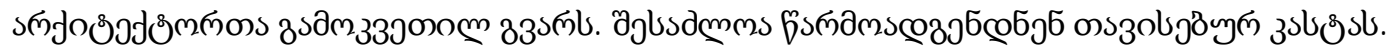

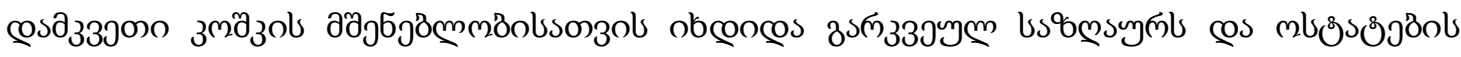

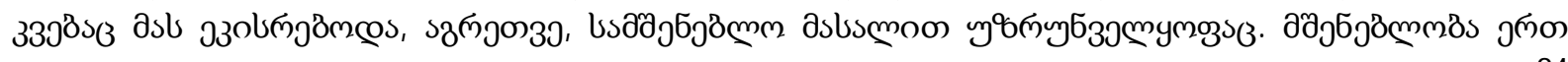




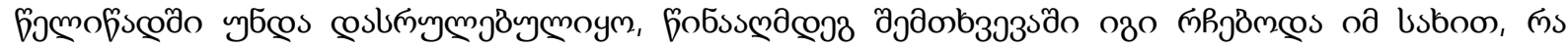

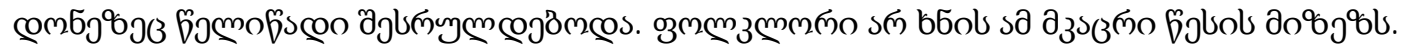

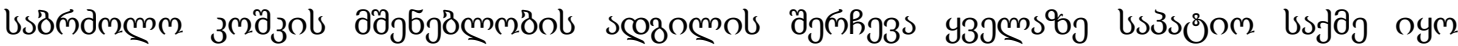

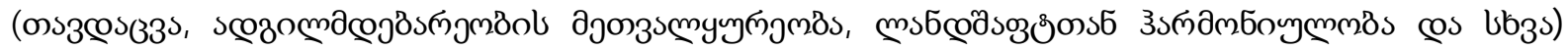

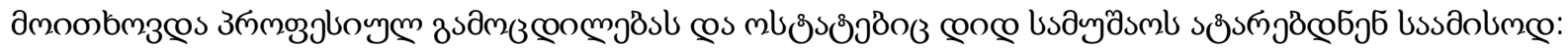

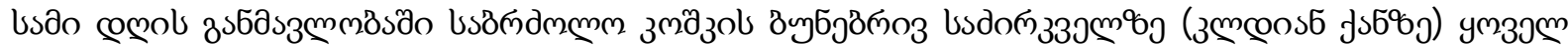

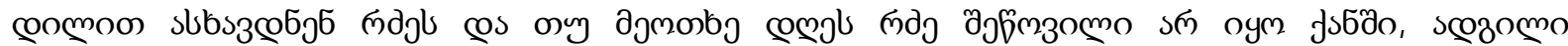

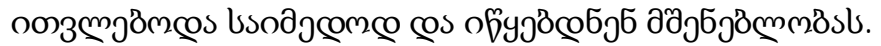

œоœо дбодзб

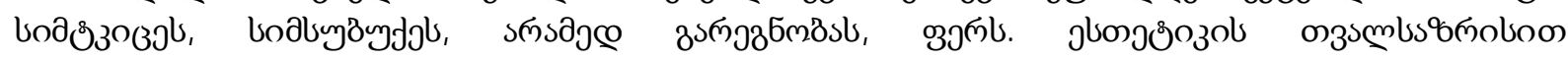

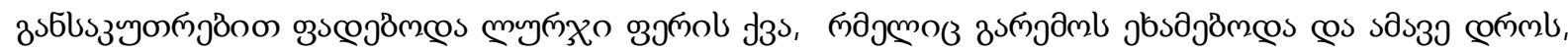

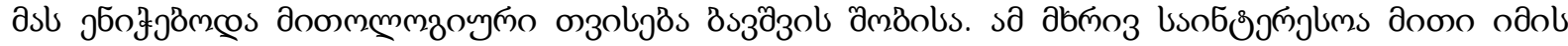

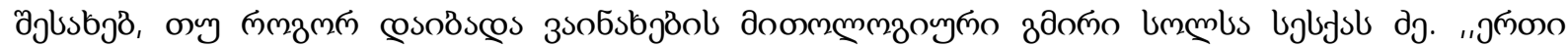

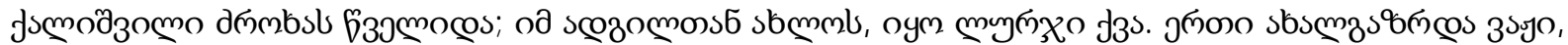

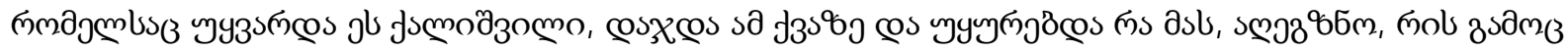

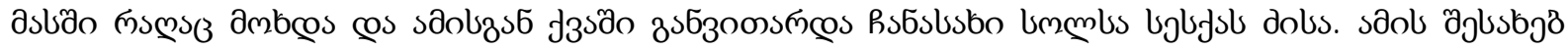

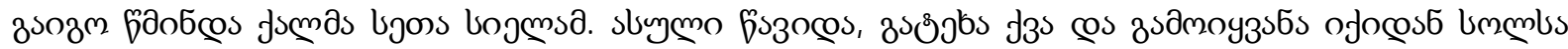
uglofsus do.

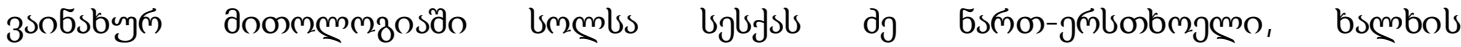

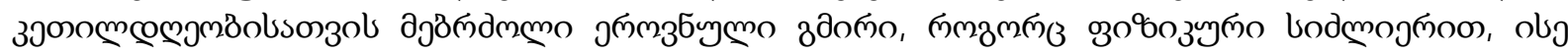

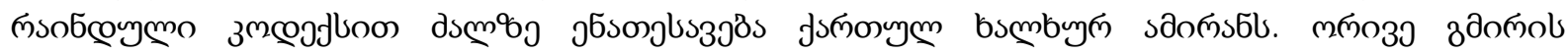

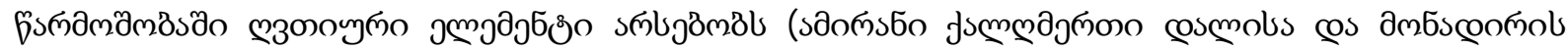

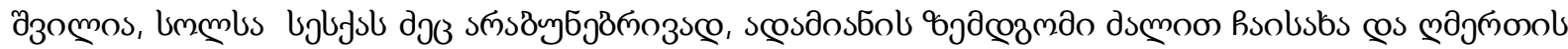

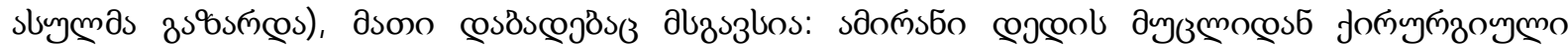

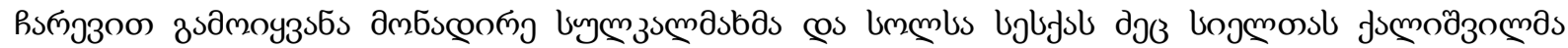

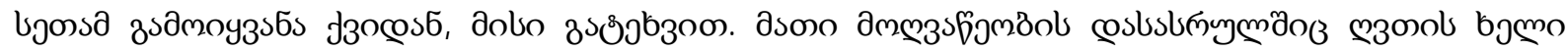

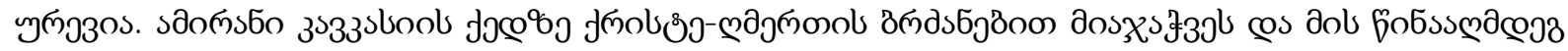

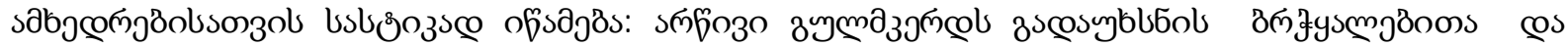

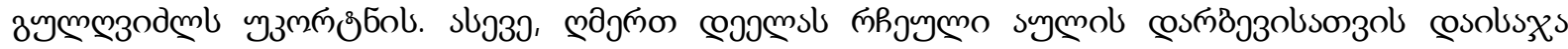

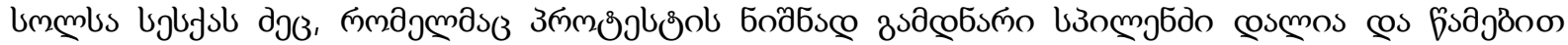
дмззщеs.

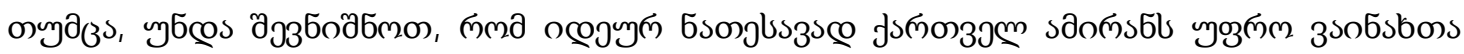

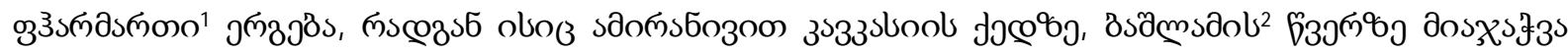

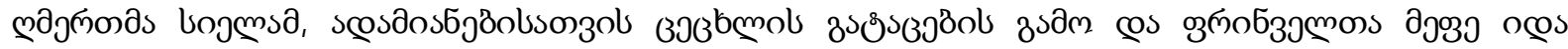

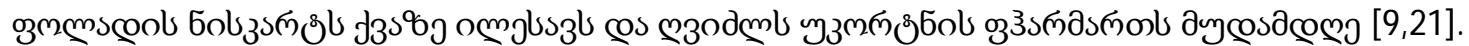

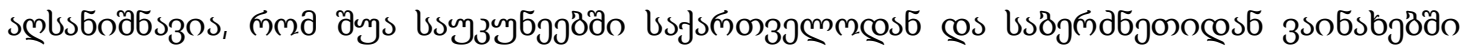

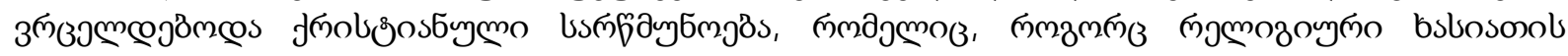

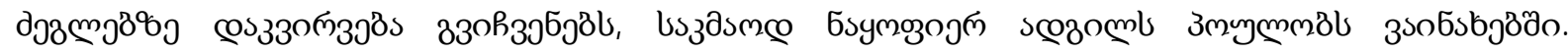

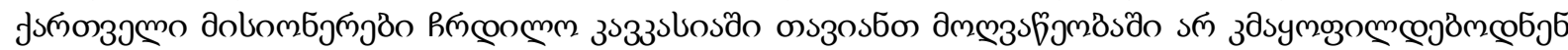

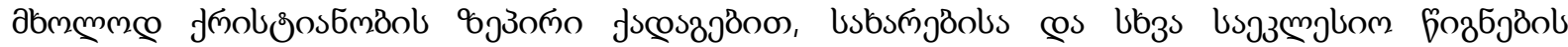

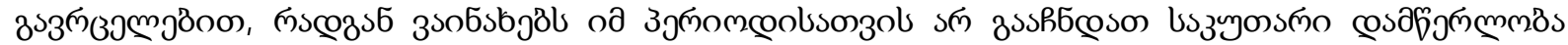

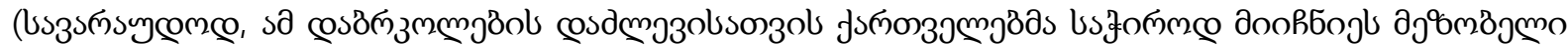

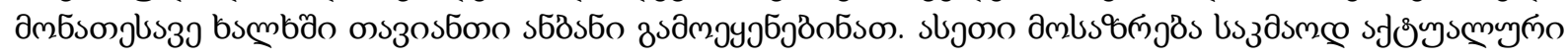

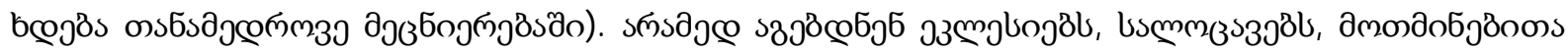

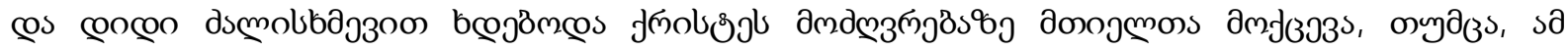

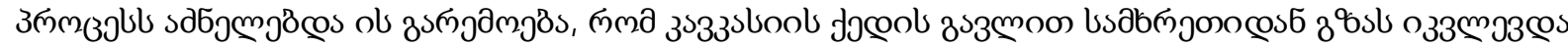

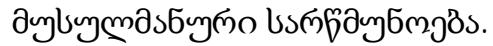

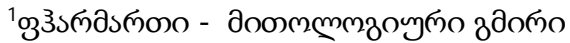

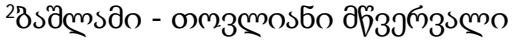




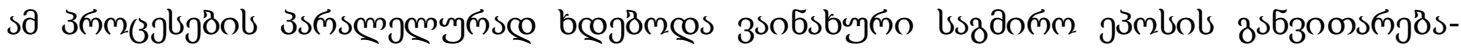

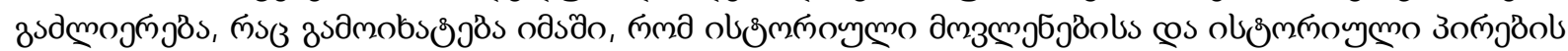

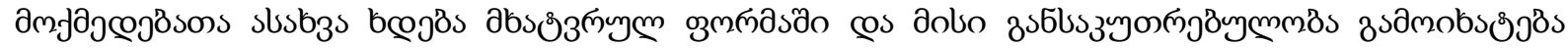

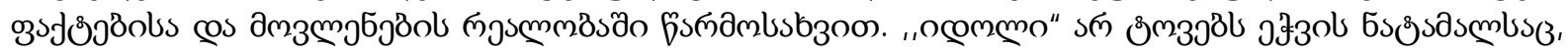

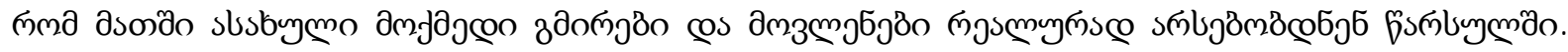

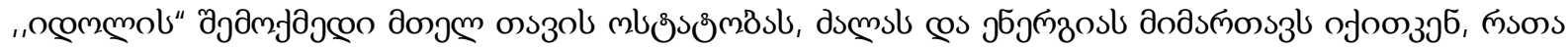

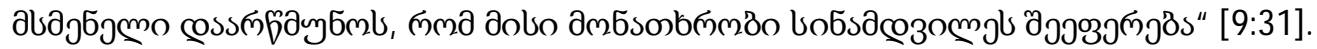

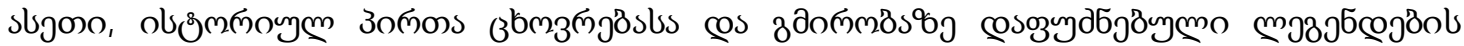

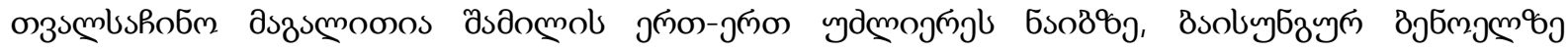

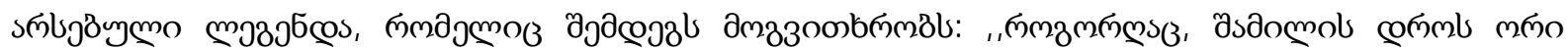

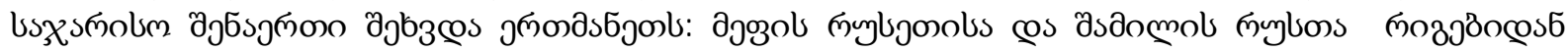

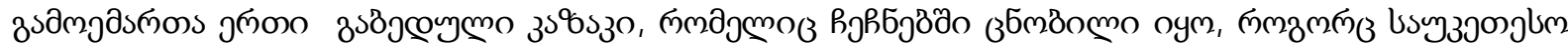

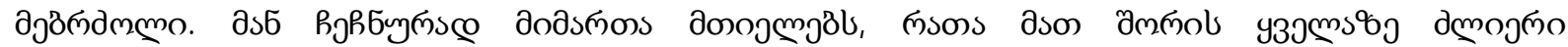

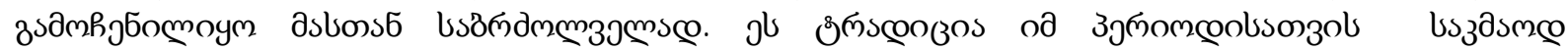

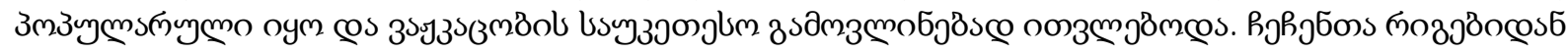

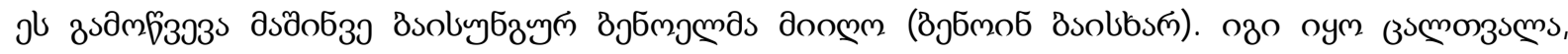

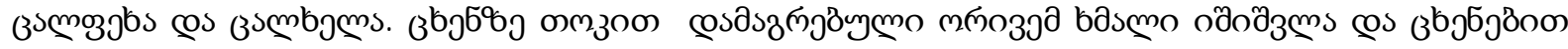

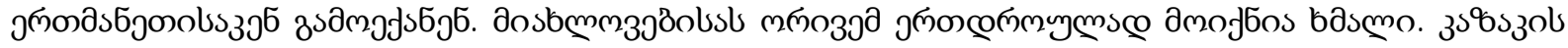

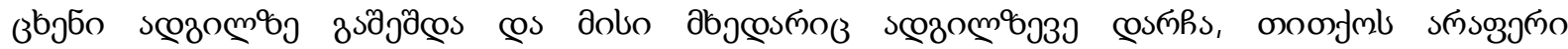

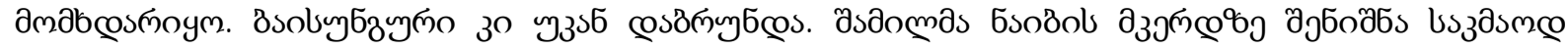

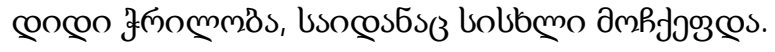

odsads fsamodsbs:

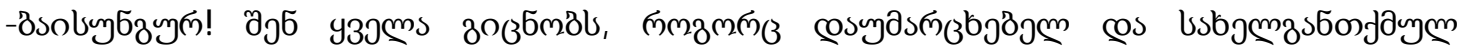

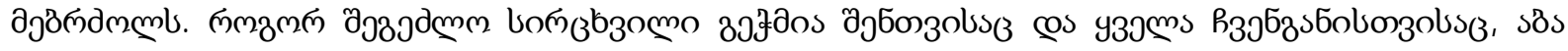

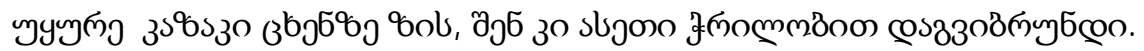

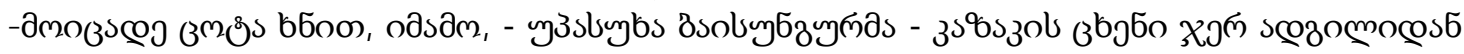

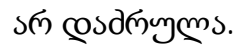

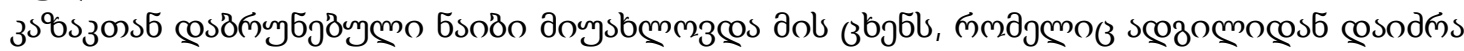

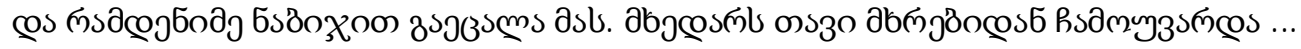

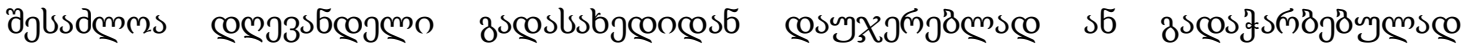

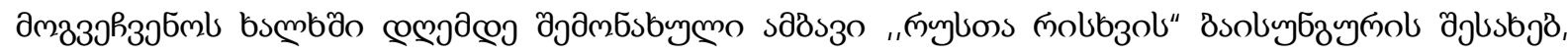

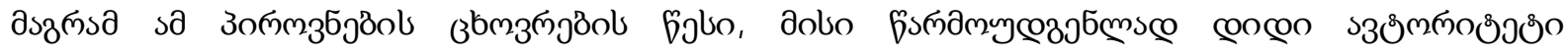

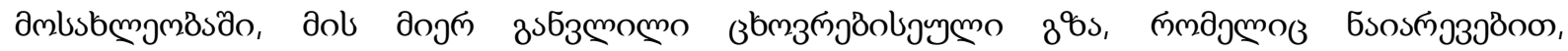

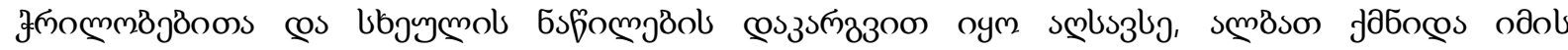

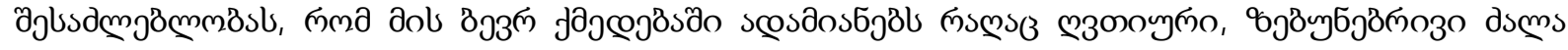

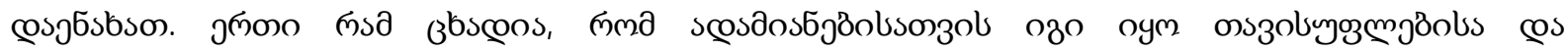

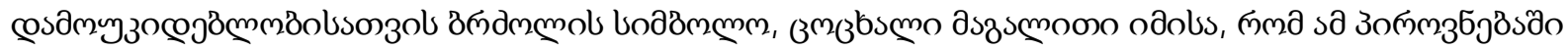

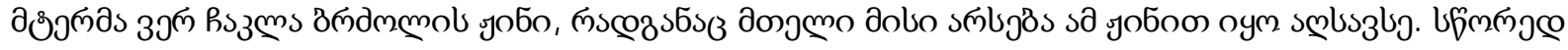

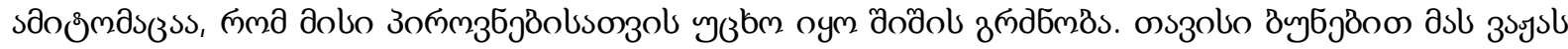

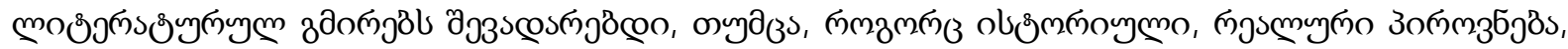

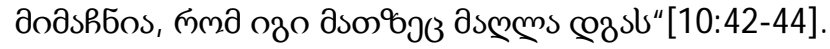

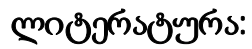

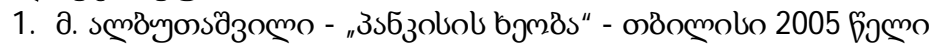

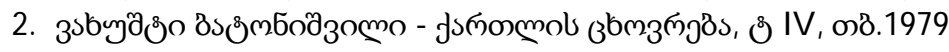

3. Пицхелаури К. Дедабришвили Ш, - Работы кахетинской археологической экспедиции в зоне строительство верхне-алазанской оросительной системы (1965-1969) ТКАЭ, І, Тб. 1969.

4. Ахриев Ч. Ингушские праздники, ССКГ, Вып.5, Тифлис, 1871

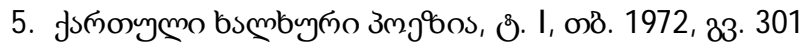


6. Яковлев Н. - Ингуши Популярный очерк, Государственное издательство, москва-ленинград 1925

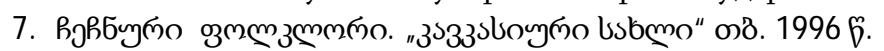

8. Танкиев А. Х. Духовные башни Ингушского народа, Саратов 1997 г.

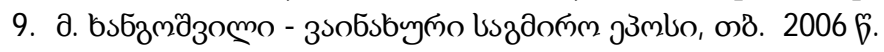

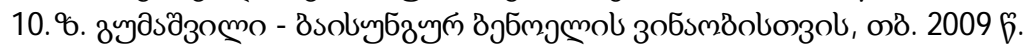

\title{
Vainakh mythological searches
}

Gumashvili Zaur

Iakob Gogebashvili State University, Telavi

\begin{abstract}
The goal of studies to represent mythological picture of Kist ethnicity that goes back to ancient times. Diversity of the Vainakh people mythology worth attention.

In the study there is shown that Vainakh Version of epos appears to be the part of General Caucasian Narts epos that have parallels with other Caucasus people too.

Some of epic heroes preserved their ancient characteristic that gives us opportunity to see half-gods in them. Beside this the epos helps us to make clear picture of Vainakh divers mythology as well as the traces of ancient civilization.
\end{abstract}

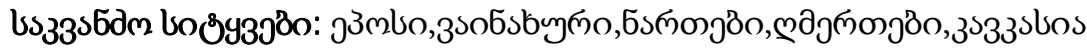

Keywords: Epos, Vainakh, Narts, Gods, Caucasus 